\title{
Thickened ascending aortic wall mimicking intramural hematoma.
}

\author{
Kentaro Yamane \\ Thomas Jefferson University \\ Hitoshi Hirose \\ Thomas Jefferson University \\ Benjamin A. Youdelman \\ Thomas Jefferson University \\ James Diehl \\ Thomas Jefferson University
}

Follow this and additional works at: https://jdc.jefferson.edu/surgeryfp

Part of the Surgery Commons

Let us know how access to this document benefits you

\section{Recommended Citation}

Yamane, Kentaro; Hirose, Hitoshi; Youdelman, Benjamin A.; and Diehl, James, "Thickened ascending aortic wall mimicking intramural hematoma." (2012). Department of Surgery Faculty Papers. Paper 78.

https://jdc.jefferson.edu/surgeryfp/78

This Article is brought to you for free and open access by the Jefferson Digital Commons. The Jefferson Digital Commons is a service of Thomas Jefferson University's Center for Teaching and Learning (CTL). The Commons is a showcase for Jefferson books and journals, peer-reviewed scholarly publications, unique historical collections from the University archives, and teaching tools. The Jefferson Digital Commons allows researchers and interested readers anywhere in the world to learn about and keep up to date with Jefferson scholarship. This article has been accepted for inclusion in Department of Surgery Faculty Papers by an authorized administrator of the Jefferson Digital Commons. For more information, please contact: JeffersonDigitalCommons@jefferson.edu. 


\title{
As submitted to:
}

\section{Asian Cardiovascular and Thoracic Annals}

\author{
And later published as:
}

\section{Thickened ascending aortic wall mimicking intramural hematoma}

\section{Volume 20, April 2012, Pages: 208-209.}

\section{DOI: $10.1177 / 0218492311423846$}

\author{
Kentaro Yamane, Hitoshi Hirose, Benjamin A Youdelman and James T Diehl
}

A 45-year-old Hispanic woman presented with a 3-day history of "burning" chest pain. A computed tomo- graphic angiogram of the chest revealed the ascending aorta had a maximum diameter of $40 \mathrm{~mm}$ with marked thickening of the aortic wall (Figure 1), which we con- cluded was an intramural hematoma. On entering the pericardium, a milky-white plaque-like area on the ascending aorta was encountered (Figure 2). The ascending aorta was firm to palpation. Intraoperative transesophageal echocardiography and epiaortic ultra- sound showed a hyperechoic aortic wall with no find-ings compatible with aortic dissection. The ascending aorta had an irregular surface contour, which was unli- kely to be a finding of aortic dissection (Figure 3A, arrow). The transverse arch, proximal innominate artery, and left carotid artery also showed thickened walls (Figures 3B and 3C). We decided not to replace the ascending aorta. Pathology of the surface of the ascending aorta revealed a chronic inflammatory infiltrate with lymphocytes and plasma cells, dense fibrosis, and granulation. Serological studies were inconclusive. The patient was started on steroid therapy for possible isolated aortitis or aortitis syndrome, and her symptoms subsided with a normalized erythrocyte sedimentation rate and C-reactive protein level. She was doing well with a stable chest radiograph 10 months after the surgery

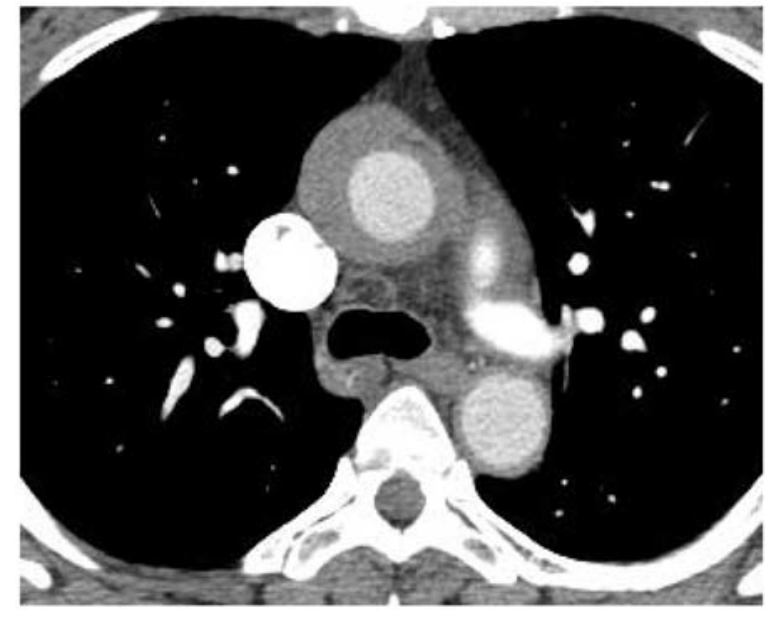

Figure 1. Computed tomographic angiogram of the chest showing the ascending aorta with a maximum diameter of $40 \mathrm{~mm}$ and marked thickening of the aortic wall.

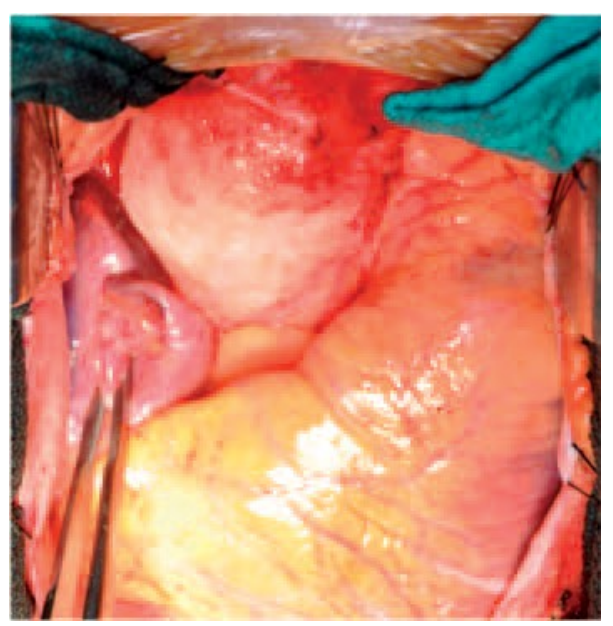

Figure 2. The milky-white plaque-like area on the ascending aorta. 
Figure 3. (Top) The irregular surface contour of the ascending aorta. (arrow). (Botom) The transverse arch, proximal innominate artery, and left carotid artery also showed thickened walls.

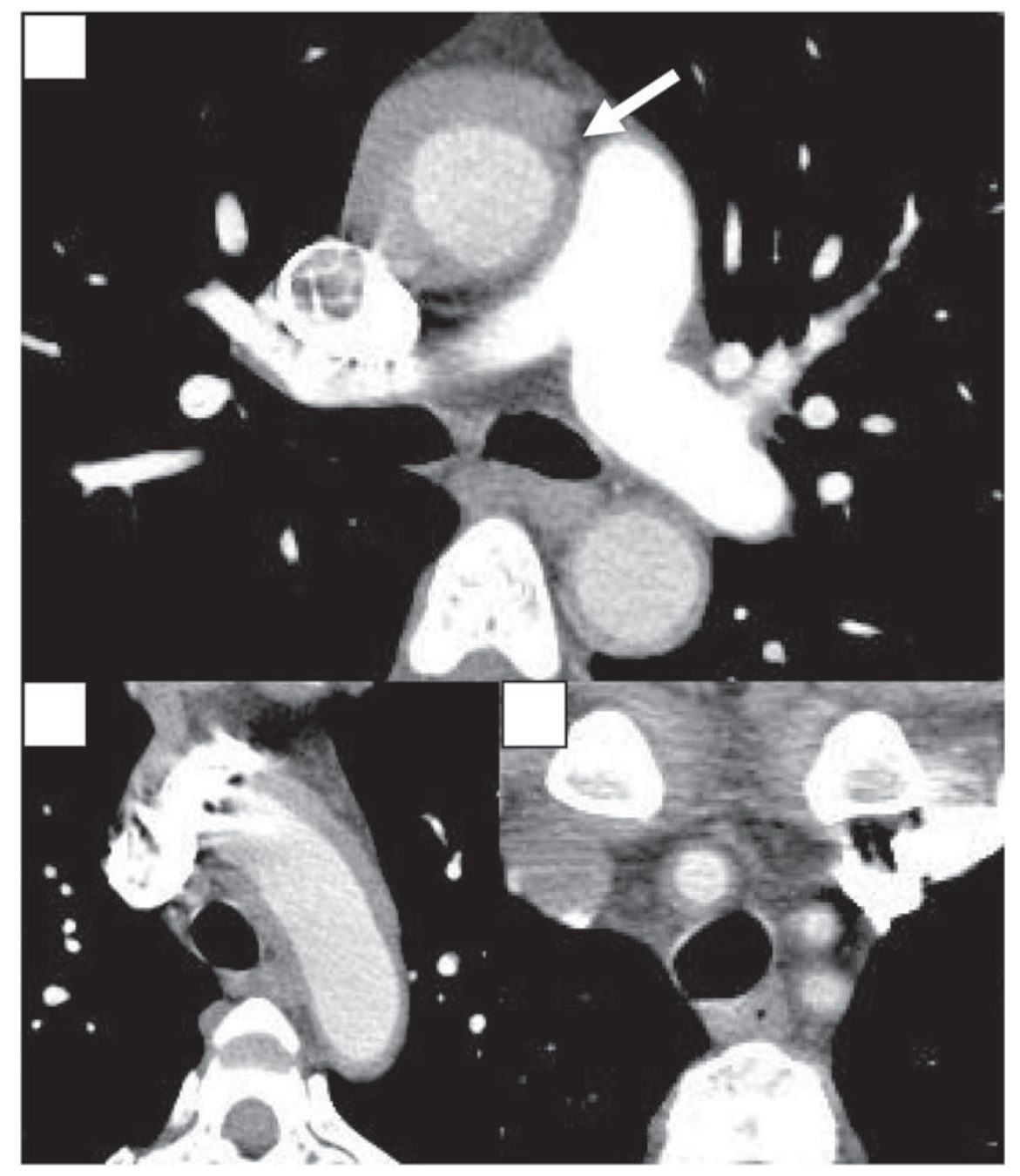


